Çukurova Üniversitesi Mühendislik Fakültesi Dergisi, 36(3), ss. 799-813, Eylül 2021

Cukurova University Journal of the Faculty of Engineering, 36(3), pp. 799-813, September 2021

\title{
Afşin-Elbistan Termik Santral Külünün Standarda Uygun Hale Getirilmesi ve Beton Katkısı Olarak Değerlendirilmesi
}

\author{
Hüseyin TEMİ* ${ }^{*}$, Kadir ELBISSTAN², Betül PAKÖZ3 \\ ${ }^{1}$ Kahramanmaraş Sütçü İmam Üniversitesi, Mühendislik ve Mimarlık Fakültesi, İnşaat \\ Mühendisliği Bölümü, Kahramanmaraş \\ ${ }^{2}$ Devlet Su İşleri 20. Bölge Müdürlüğ̈̈, Kahramanmaraş \\ ${ }^{3}$ Kahramanmaraş Sütçü Imam Üniversitesi, Mühendislik ve Mimarlık Fakültesi, İnşaat \\ Mühendisliği Bölümü, Kahramanmaraş
}

Geliş tarihi: 25.06.2021 Kabul tarihi: 13.09.2021

\section{Özet}

Türkiye'de sanayinin gelişmesi ve yaygınlaşması için enerjiye gereksinim vardır. Bu nedenle enerji üretiminin artırılması, enerjiden tasarruf sağlanması ve binaların yalıtımına önem verilmesi, atık maddelerin değerlendirilmesi gibi konuların önemi giderek artmaktadır. 2019 yılı verilerine göre Türkiye'de elektriğin yaklaşık \%57,8'i fosil yakıtlardan üretilmektedir. Fosil yakıtların yaklaşı \%65'ini kömür oluşturmaktadır. Kahramanmaraş Afşin-Elbistan Termik Santrali, linyit kömürü ile elektrik üreten santrallerden biridir. Afşin-Elbistan Termik Santrali'nde yılda yaklaşık iki milyon ton uçucu kül üretilmekte ve bu külün çok azı kullanılmaktadır. Bu uçucu külün yeterince kullanılmamasının nedeni; kimyasal yapısının standartların öngördüğü kriterlere uygun olmamasıdır. Atık külün depolama sorunu yanında, çevrenin kirlenmesine önemli derecede etkisi de bulunmaktadır. Diğer yandan endüstriye kazandırılması halinde ülke ekonomisine önemli oranda katkı sağlaması bilinen bir gerçektir. Bu deneysel çalışmada, Kayseri bimsi, cam atığı tozu, az oranda kolemanit ilaveleriyle Afşin-Elbistan Termik Santrali uçucu külü (AEUK) standarda uygun hale getirilmiştir. Basınç dayanımı, priz süresi, hacimsel genleşme, donma-çözülme gibi deneyler yapılmıştır. Katkı maddeleri sayesinde, AEUK'nın betonda kullanılabileceği ortaya çıkarılmıştır.

Anahtar Kelimeler: Basınç dayanımı, Bims, Dayanıklılık, Kolemanit, Uçucu kül

\section{Investigation of the Effects of Afşin-Elbistan Thermal Power Plant Ash on Concrete}

\begin{abstract}
Turkey are in need of energy for development and expansion of the industry. For this reason, issues such as increasing energy production, saving energy and attaching importance to the insulation of buildings, and utilizing waste materials are increasing. According to data from 2019 , about $57.8 \%$ of electricity is produced from fossil fuels in Turkey. About $65 \%$ of fossil fuels are coal. Kahramanmaraş Afşin-Elbistan Thermal Power Plant is one of the power generating plants with lignite coal. Approximately two million tons of fly ash is produced annually at Afşin-Elbistan Thermal Power Plant and very little of this ash is used. The reason why this fly ash is not used enough; chemical structure does not meet the criteria stipulated by the standards. In addition to the storage problem of waste ash, it also has a significant
\end{abstract}

*Sorumlu Yazar (Corresponding Author): Hüseyin TEMİ, htemiz@ksu.edu.tr 
impact on environmental pollution. On the other hand, it is a known fact that if it is brought into the industry, it will contribute significantly to the national economy. In this experimental study, Kayseri pumice, glass waste powder, and the low powder colemanite additions, Afşin-Elbistan Thermal Power Plant fly ash were made compatible with the standard. Thanks to the additives, it was determined that the adverse effects of Afşin-Elbistan Thermal Power Plant fly ash on concrete were eliminated.

Keywords: Bims, Colemanite, Compressive strength, Durability, Fly ash

\section{GíRiș}

2019 verilerine göre Türkiye'de elektrik üretiminde en büyük pay $\% 37$ ile kömür santrallerinin olmuştur. Doğalgazın oranı 2018'e göre \%31'den \%18,86'ya inmiştir. İki fosil kaynağın toplamı \%57,8'dir [1].

Beton diğer yap1 malzemelerine göre; daha kolay şekil verilebilir olması, ekonomik ve dayanıklı olması, üretiminde daha az enerji tüketilmesi, her yerde üretilebilir ve estetik olması özellikleriyle en çok kullanılan yapı malzemesidir [2]. Bununla beraber bazı durumlarda normal dayanımlı betonun kullanımı yetersiz kalmaktadır. Betondan sadece dayanım değil bunun yanında durabilite de istenmektedir. $\mathrm{Bu}$ durumda betonun durabiliteye göre tasarımı ön plana çıkmaktadır. Genel olarak betonun çevresel etkilere diğer bir deyişle durabiliteye göre tasarımı bu iki parametreye göre yapılır. Betondaki maksimum su/çimento oranı ve minimum çimento dozajı gibi kısıtlamaların ne ölçüde gerçekleşebileceği (yani çevresel etki sınıfına bağlı olarak maksimum su/çimento oranı belirli bir değeri aşamaz ve çimento dozajı da öngörülen minimum değerin altına inemez) doğrudan beton agregasının türüne, granülometrisine ve standartlarına uygun olmasina bağlıdır [3].

Kömür yakan termik santrallerin bir yan ürünü olan uçucu kül yapay puzolandır. Uçucu külün beton yapımında kullanılabilmesi için sahip olması gereken özellikler ve sinırlamalar standartlarda belirtilmektedir. $\mathrm{Bu}$ sınırlamaların bazıları $\mathrm{SO}_{3}$ içeriği, serbest $\mathrm{CaO}$ içeriği, $\mathrm{MgO}$ içeriği, alkali oksit içeriği olarak sıralanabilir. Bu kimyasal içerikleri yüksek olan küller, çimento ikamesi için veya kompoze çimento üretilmesinde kullanılamamaktadır. Dolayısıyla bu küller depo sahalarında uzun yıllar saklanmakta, zamanla yeraltı suyuna karışarak veya havalanarak kirlilik ve çevresel tehdit oluşturabilmektedir [4]. Uçucu kül katkısı genel olarak betonun kohezif özelliğini arttırmakta; ancak akışkanlığını azalttığı için bir akışkanlaştırıcı madde ile birlikte kullanılması gerekebileceği belirtilmektedir [5]. Puzolanların kullanım amaçları arasında beton teknolojisinde enerji tasarrufu sağlamak, taze ve sertleşmiş betona bazı yeni özellikler kazandırılması bulunmaktadır. Puzolanların etkinlikleri, mineralojik ve kimyasal yapısına, aktivitesine, kullanım miktarına ve betonun bileşim özelliklerine bağlıdır. Yüksek miktarda $\mathrm{CaO}$ içeren C sınıfı uçucu küller ile silis dumanı betonun ilk yaşlardaki ve nihai dayanımlarını arttırmaktadır. Bunların süper akışkanlaştırıcılarla kullanılması ile yüksek mukavemetli beton üretiminde yeni bir çığır açılmıştır [6]. Uçucu küller betonda termik rötreyi önlemek için kütle betonu yapımında kullanılmaktadır. $\mathrm{Bu}$ malzemelerin doğrudan betona katılması durumunda büyük enerji tasarrufu sağlanabilir. Uçucu küller çok ince olduklarından geçirimsiz beton üretiminde de kullanılabilir [7]. Afşin-Elbistan Termik Santrali'nin 1. ve 2. ünitelerinden alınan numunelerin kimyasal analizleri yapılmıştır. Belirlenen kimyasal analiz sonuçlarına göre reaktif $\mathrm{CaO}$ oranı $(\% 53,44)$ \%10'un üzerinde olduğu için TS EN 197-1'e göre W sinıfina girdiği, $\mathrm{SiO}_{2}+\mathrm{Al}_{2} \mathrm{O}_{3}+\mathrm{Fe}_{2} \mathrm{O}_{3}$ toplam değerinin $(\% 30,69)$ \%50'nin altında kalmas1 nedeniyle sınıf dışı kaldığı, yine $\mathrm{SiO}_{2}$ oranının $(\% 18,27) \% 25$ 'in altında kalması nedeniyle sinif dışı olduğu belirtilmiştir [8]. Diğer taraftan Afşin Elbistan Termik Santrali, ülkemizdeki en yüksek enerji üretme ve yan ürün olarak uçucu kül üretme kapasitesine sahiptir. Üretilen uçucu külün içerdiği yüksek serbest $\mathrm{CaO}$, düşük $\mathrm{SiO}_{2}$ ve yükssek $\mathrm{SO}_{3}$ oranları nedeniyle TS EN 197-1'e uymadığı için tüketim oranı düşük kalmakta çözüm olarak depolama yoluna gidilmektedir [9]. 
Pomza oluşumu sırasında bünyedeki gazların ani olarak bünyeyi terk etmesi ve ani soğuma nedeniyle, makro ölçekten mikro ölçeğe kadar sayısız gözenek içerir. Gözenekler arası genelde bağlantısız boşluklu olduğundan hafif, suda uzun süre yüzebilen, permeabilitesi düşük ve yalıtımı oldukça yüksektir. Kimyasal olarak \%75'e varan silis içeriği bulunabilmektedir. Kayacın içerdiği $\mathrm{SiO}_{2}$ oranı, kayaca abrasif özellik kazandırmaktadır. $\mathrm{Al}_{2} \mathrm{O}_{3}$ bileşimi ise ateş ve ısıya yüksek dayanım özelliği kazandırır. Türkiye'de pomza yatakları, Ürgüp-Avanos ve Kayseri'nin Talas, Tomarza-Develi bölgesinde yoğunlaşmıştır. Ayrıca Bitlis, Van, Ağrı, Kars, Ankara, Isparta ve Muğla illerinde bulunmaktadır [10].

Bor kristalize görünüm ve optik özellikleri bakımından elmasa benzer ve neredeyse elmas kadar serttir. Günümüzde Dünya bor rezervlerinin ve üretiminin en fazla olduğu iki ülke A.B.D. ve Türkiye'dir. Önemli üretici ülkelerin bu üretimdeki payları sırasıyla, Türkiye \%33, A.B.D. \%28, Rusya \%23 ve diğer ülkeler \%16 düzeyindedir [11].

Amorf yapıya, yüksek silis $\left(\mathrm{SiO}_{2}>\% 70\right)$ içeriğine ve yüksek yüzey alanına sahip olan camın geri dönüşümü çevresel bir konudur. Çevrede bulunan camın erimez yapısı ve aşırı geri dönüşüm maliyeti geri dönüşümünü zorlaştırmaktadır. Puzolanik özellik gösteren çimento inceliğindeki cam tozu alternatif bir çimento katkı malzemesi olarak değerlendirilebilmektedir. Cam tozundan beklenen etki beton veya harcın dayanım ve dayanıklılığının iyileştirilmesidir. Amorf cam tozu puzolanik aktivite göstermesi sayesinde çimento ve suyun hidratasyonu sonucunda oluşan $\mathrm{Ca}(\mathrm{OH})_{2}$ 'i, içeriğinde yüksek oranda bulunan $\mathrm{SiO}_{2}$ ile bağlayarak betona dayanım kazandıran kalsiyum silika hidrat (C-S-H) jellerini oluşturmaktadır [12].

Yapılan araştırmada cam tozunun betonun basınç dayanımı üzerine etkileri incelenmiştir. Araştırmada çimento yerine sırasıyla \%10, \%15 ve $\% 20$ oranlarda cam tozu alınarak karışımlar hazırlanmış ve numunelerin 7 günlük ve 28 günlük basınç dayanımları test yöntemi ile bulunmuştur. Katkılı numunelerden bulunan basınç dayanımı değerleri referans numune basınç dayanımı değeri ile karşılaştırılmıştır. Cam tozu katkılı numunelerden elde edilen basınç dayanımı değerinin referans numune basınç dayanımından yaklaşık \%20 daha büyük çıktığı belirtilmiştir [13].

$\mathrm{Bu}$ araştırmada, Kayseri pomzası (bims), cam atı̆̆1 tozu, az oranda kolemanit ilaveleriyle AEUK'nın kimyasal yapısı standarda uygun hale getirilmiştir. Katk1 maddeleri sayesinde, AEUK'nın neden olduğu olumsuz etkilerinin giderildiği belirlenmiştir.

\section{MATERYAL VE METOT}

\section{Çalışmada kullanılan AEUK Afşin-Elbistan} Termik Santralinden, Kayseri pomzası (KP) Kayseri yöresinden, kolemanit (KO) Balıkesir/Bigadiç çevresinden sağlanmış ve cam tozu (CT) ise camciların atık camlarından elde edilmiştir. Şekil 1'de toz halindeki mineral katk1 maddeleri görülmektedir.
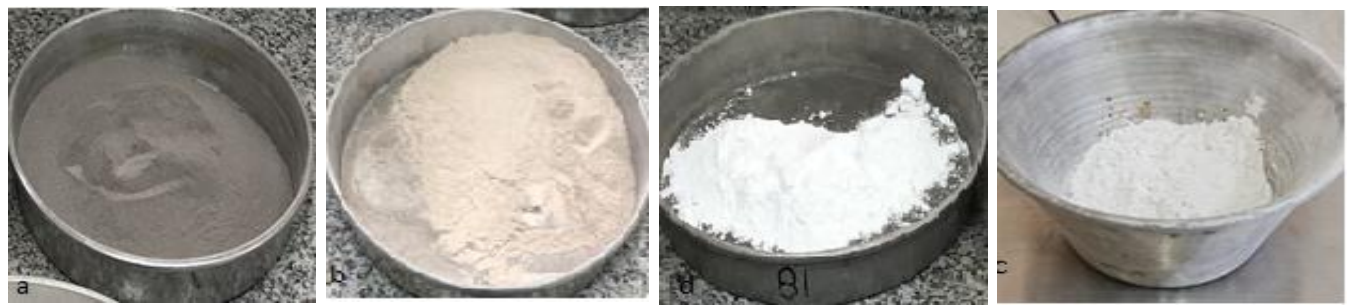

Şekil 1. a) AEUK, b) P, c) K, d) C AEUK'nın standarda uygun hale getirilerek
C40/50 $\mathrm{MPa}$ dayanıml beton üretilmesi hedeflenmiştir. Deneylerde kullanılan bağlayıcı malzemelerin bazı kimyasal ve fiziksel analizleri 
Çizelge 1 ve 2'de verilmiştir. Araştırmada optimum karışım oranlarının belirlenmesi amacıyla eksiltilen CEM I çimentosunun yerine kütlece \% olarak beş farklı oranda AEUK ve ince öğütülmüş cam tozu (CT), pomza (KP) ve kolemanit tozları (KO) kullanılmıştır. Değişik oranlarda katkı seçilmesinde numunelerin dayanım, dayanıklılık ve ekonomik olması gibi amaçlar esas alınmıştır. Çizelge 3'te deneme karışımları verilmiştir. Her bir karışım için altı adet $10 \mathrm{~cm}$ boyutlu beton küp numuneleri üretilmiştir. Numunelerin 7 ve 28 günlük basınç dayanımı değerleri ve malzemelerin kimyasal analizleri göz önünde bulundurularak optimum karışım oranı belirlenmiştir. Buna göre, yeni karışımda çimento miktarı kütlece \%40 azaltılmış yerine \%20 AEUK, \%10 KP, \%5 KO ve $\% 5$ CT kullanılmış ve miktarlar Çizelge 4'te verilmiştir. Araştırmanın bundan sonraki bölümünde üretilen numuneler Çizelge 4'te verilen referans (REF) ve karışım (6)'da belirtilen oranlar kadar alınmıştır. Beton karışım hesabında TS 802 esas alınmıştır [14].

Çizelge 1. Bağlayıcı malzemelerin kimyasal özellikleri

\begin{tabular}{|l|c|c|c|c|c|c|c|c|c|}
\hline Katkı türü & $\mathbf{S i O}_{2}$ & $\mathbf{A l}_{2} \mathbf{O}_{3}$ & $\mathbf{F e}_{2} \mathbf{O}_{3}$ & $\mathbf{C a O}$ & $\mathbf{M g O}$ & $\mathbf{S O}_{3}$ & $\mathbf{K}_{2} \mathbf{O}$ & $\mathbf{N a} \mathbf{O}$ & K. Kaybı \\
\hline CEM I 42.5R & 19,40 & 5,36 & 3,79 & 64,30 & 2,25 & 2,47 & 0,90 & 0,09 & 1,44 \\
\hline $\begin{array}{l}\text { CEM 1 } \\
\text { AEUK }\end{array}$ & 26,83 & 6,62 & 3,47 & 47,96 & 1,40 & 3,96 & 1,02 & 0,92 & 5,79 \\
\hline $\begin{array}{l}\text { Çimentosuz } \\
\text { AEUK }_{20}+\mathrm{KP}_{10}+\mathrm{KO}_{5}+\mathrm{KO}_{5}+\mathrm{CT}_{5}\end{array}$ & 40,33 & 9,27 & 4,53 & 24,15 & 2,09 & 5,32 & 1,10 & 2,15 & 7,58 \\
\hline
\end{tabular}

Çizelge 2. Bağlayıı malzemelerin fiziksel özellikleri

\begin{tabular}{|l|c|c|c|c|}
\hline Malzeme & $\begin{array}{c}\text { Özgül ağırlık } \\
\left(\mathbf{g r} / \mathbf{c m}^{\mathbf{3}}\right)\end{array}$ & $\begin{array}{c}\text { Özgül yüzey } \\
\left(\mathbf{c m}^{2} / \mathbf{g r}\right)\end{array}$ & \multicolumn{2}{|c|}{ Elek üzeri kalan (\%) } \\
\cline { 4 - 5 } & 3,15 & 3480 & $\mathbf{9 0} \boldsymbol{\mu}$ & $\mathbf{4 5} \boldsymbol{\mu}$ \\
\hline $\begin{array}{l}\mathrm{CEM} \mathrm{I} \mathrm{42,5R} \\
\mathrm{AEUK}_{60}+\end{array}$ & 2,93 & 3790 & 0,1 & 8,2 \\
\hline
\end{tabular}

Çalışmada kullanılan agrega Aksu-Nehir malzemesinden agrega üreten işletmeden temin edilmiştir. İşletmeden alınan dere agregası kırılmış ve kırılmamış karışımlardan meydana getirilmektedir. Agreganın tane dağılımı TS EN 12620 'de öngörülen kriterlere uygun hale getirilmiştir [15]. Agreganın tane dağılımı Şekil 2'de verilmiştir.

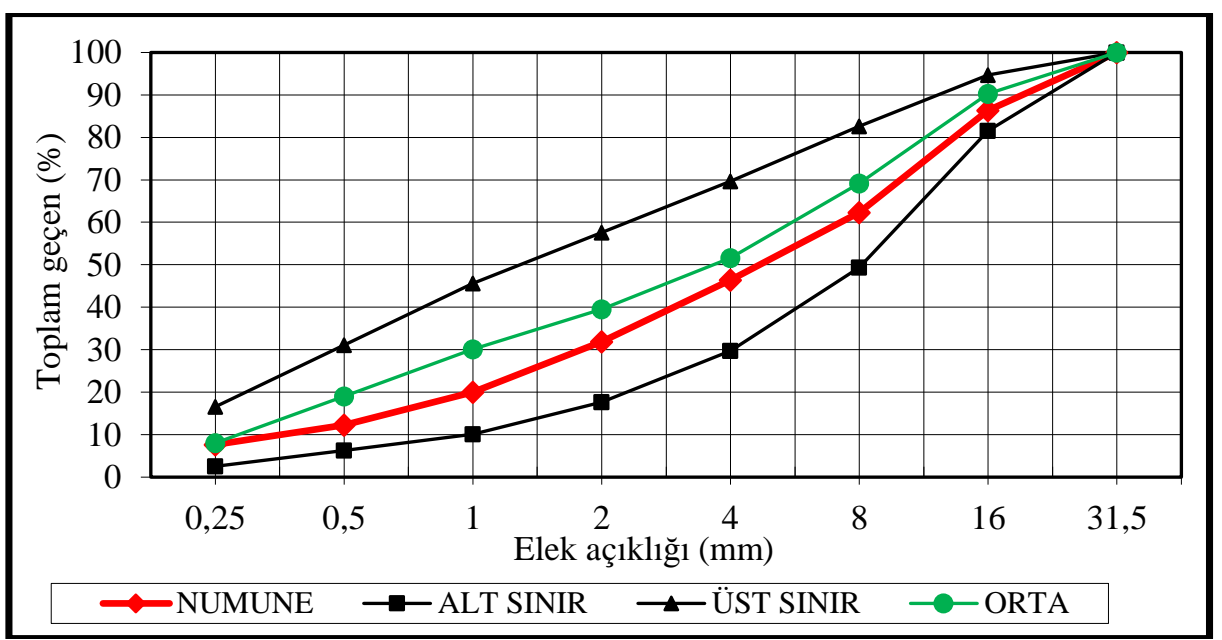

Şekil 2. Agreganın tane dağılımı 
Kumun özgül ağırlığ $2,66 \mathrm{~kg} / \mathrm{dm}^{3}$, çakılın özgül ağırlığ $2,7 \mathrm{~kg} / \mathrm{dm}^{3}$; su emme oranları ise kumda $\% 1,9$, ince çakılda $\% 0,4$ ve iri çakılda $\% 0,3$ bulunmuştur.

Çalışmalarda beton karışımı için önerilen sınır değerler TS EN 206 'ya göre zararlı kimyasal ortam XA3 sınıfı ortam standartlarına göre tasarım yapılmıștır. C40/50 $\mathrm{MPa}$ dayanımlı beton üretilmesi hedeflenmiştir. Karıșımlarda çimento dozaj1 $420 \mathrm{~kg} / \mathrm{m}^{3}$ alınmıştır. S/Ç oranı 0,44 olarak alınmış ve taze betonun slump (çökme) değeri 13 cm olarak belirlenmiştir. (TS 802, 2009 ve TS EN 2006, 2013). Taze betonda aynı çökme değerlerini bulmak için bir ticari ürün olan süper akışkanlaştırıcı kullanılmıştır.

Çizelge 3. $1 \mathrm{~m}^{3}$ beton karışımı için malzeme miktarları (deneme)

\begin{tabular}{|c|c|c|c|c|c|c|c|c|c|c|}
\hline \multirow[b]{2}{*}{ Numune adı } & \multicolumn{5}{|c|}{ Beton bileșenleri $\left(\mathrm{kg} / \mathrm{m}^{\mathbf{3}}\right)$} & \multicolumn{5}{|c|}{ Katkı malzemeleri $\left(\mathrm{kg} / \mathrm{m}^{3}\right)$} \\
\hline & Su & CEMI & 4/12 & $\begin{array}{l}\text { kıl } \\
12 / 24\end{array}$ & Kum & $\begin{array}{l}\text { Kim. } \\
\text { katkı }\end{array}$ & KO & $\mathbf{K P}$ & CT & AEUK \\
\hline REF & 184,8 & 420 & 447 & 536 & 792 & 0,42 & & & & \\
\hline $\begin{array}{l}\text { 1. }\left(\mathrm{CEM}_{80}+\mathrm{KO}_{5}+\right. \\
\left.\mathrm{KP}_{5}+\mathrm{AEUK}_{5}\right)\end{array}$ & 184,8 & 252 & 447 & 536 & 792 & 3,36 & 21 & 21 & 21 & 21 \\
\hline $\begin{array}{l}\text { 2. }\left(\mathrm{CEM}_{75}+\mathrm{KO}_{5}+\right. \\
\left.\mathrm{CT}_{5}+\mathrm{KP}_{5}+\mathrm{AEUK}_{10}\right)\end{array}$ & 184,8 & 315 & 447 & 536 & 792 & 3,36 & 21 & 21 & 21 & 42 \\
\hline $\begin{array}{l}\text { 3. }\left(\mathrm{CEM}_{65}+\mathrm{KO}_{10}+\right. \\
\left.\mathrm{CT}_{5}+\mathrm{KP}_{10}+\mathrm{AEUK}_{10}\right)\end{array}$ & 184,8 & 273 & 447 & 536 & 792 & 3,36 & 42 & 21 & 42 & 42 \\
\hline $\begin{array}{l}\text { 4. }\left(\mathrm{CEM}_{60}+\mathrm{KO}_{10}+\right. \\
\left.\mathrm{KP}_{10}+\mathrm{AEUK}_{20}\right) \\
\end{array}$ & 184,8 & 252 & 447 & 536 & 792 & 3,36 & 42 & 42 & - & 84 \\
\hline $\begin{array}{l}\text { 5. }\left(\mathrm{CEM}_{60}+\mathrm{KP}_{10}+\right. \\
\left.\mathrm{CT}_{10}+\mathrm{AEUK}_{20}\right)\end{array}$ & 184,8 & 252 & 447 & 536 & 792 & 3,36 & - & 42 & 42 & 84 \\
\hline
\end{tabular}

Çizelge 4. $1 \mathrm{~m}^{3}$ beton karışımı için malzeme miktarları

\begin{tabular}{|l|c|c|c|c|c|c|c|c|c|c|}
\hline \multirow{2}{*}{ Numune adı } & \multicolumn{5}{|c|}{ Beton bileşenleri $\left(\mathbf{k g} / \mathbf{m}^{\mathbf{3}}\right)$} & \multicolumn{5}{c|}{ Katkı malzemeleri $\left(\mathbf{k g} / \mathbf{m}^{\mathbf{3}}\right)$} \\
\cline { 2 - 11 } & Su & CEMI & $\begin{array}{c}\text { Çakıl } \\
\mathbf{4 / 1 2}\end{array}$ & $\mathbf{1 2 / 2 4}$ & Kum & $\begin{array}{c}\text { Kim. } \\
\text { katkı }\end{array}$ & KO & KP & CT & AEUK \\
\hline REF & 184,8 & 420 & 447 & 536 & 792 & 0,42 & - & - & - & - \\
\hline $\begin{array}{l}6 .\left(\mathrm{CEMI}_{60}+\mathrm{KO}_{5}+\right. \\
\left.\mathrm{CT}_{5}+\mathrm{KP}_{10}+\mathrm{AEUK}_{20}\right)\end{array}$ & 184,8 & 252 & 447 & 536 & 792 & 3,36 & 21 & 42 & 21 & 84 \\
\hline
\end{tabular}

Çizelge 4'te verilen değerlerin alınmasında basınç dayanımı yanında, katkı maddelerinin rezerv durumları, taze ve sertleşmiş betonların özellikleri üzerine katkıların etkileri gibi durumlar da dikkate alınmıştır.

\subsection{Metot}

Çimento hamuru için gerekli normal kıvam su oranı, priz süreleri ve hacimsel genleşme değerleri bulunmuştur. Normal kıvam su oranı ve priz süreleri vikat cihazı, hacimsel genleşme ise Le Chatelier kalıbıyla bulunmuştur. Çimento hamurunda Le Chatelier cihazı kullanılarak yapılan testle, çimento içinde bulunabilen ve su ile temas edince şişerek betona zarar verebilen, serbest $\mathrm{CaO}$ ve $\mathrm{MgO}$ 'nun çimento hamurunda oluşturduğu hacim genişlemesi miktarının ölçülmesi amaçlanmaktadır. Şekil 3.a'da Vicat cihazı ile işlem, Şekil 3.b'de Le Chatelier kalıbı ile hacimsel genleşme değerini bulma işlemi verilmiştir [16]. 
Afşin-Elbistan Termik Santral Külünün Standarda Uygun Hale Getirilmesi ve Beton Katklsı Olarak Değerlendirilmesi
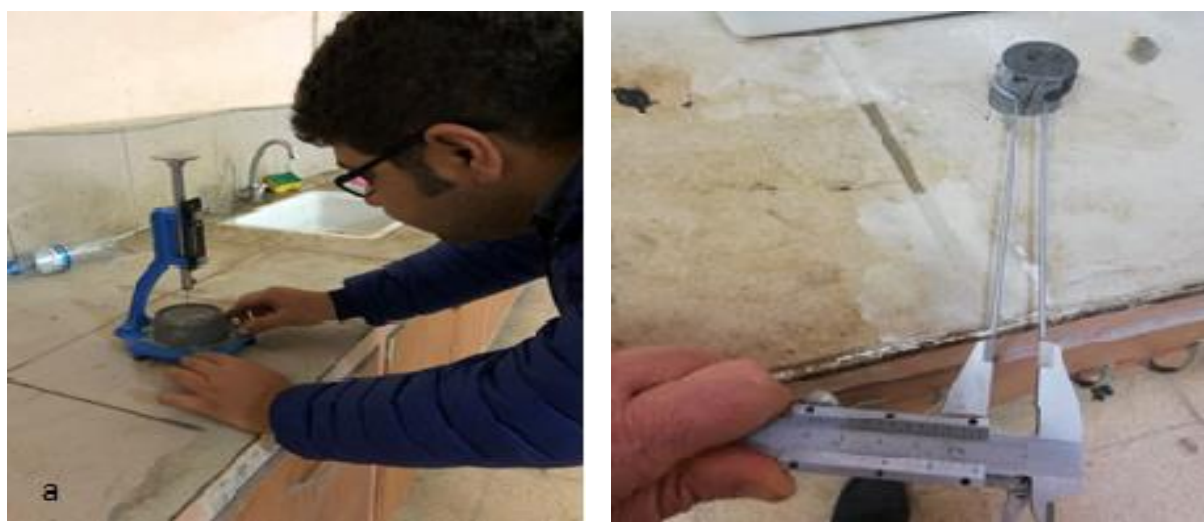

Şekil 3. a) Priz süresi tayini işlemi, b) Hacimsel genleşme işlemi

Taze betonun işlenebilmesi hakkında bilgi edinmek için çökme testi işlemi yapılmıştır. Test işleminde çökme hunisinden yararlanılmıştır.
Beton karıştırılması ve çökme değerinin bulunması işlemi Şekil 4'te görülmektedir.
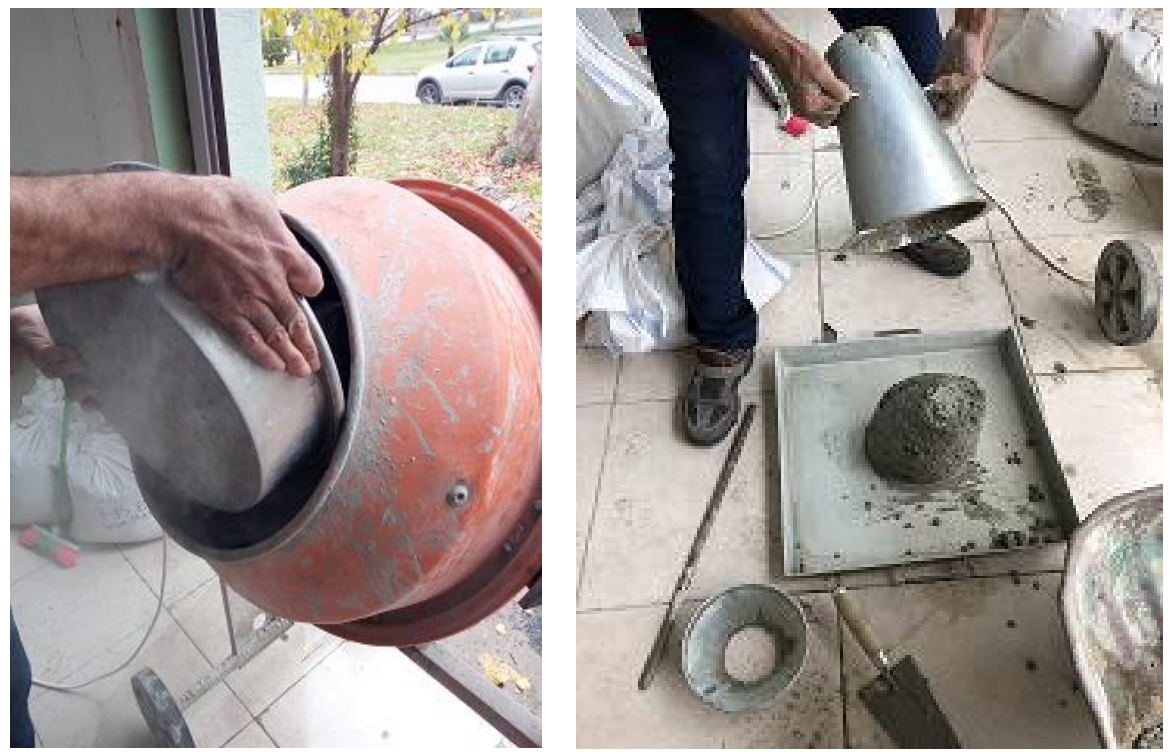

Şekil 4. Betonun karıștırılması ve çökme değerinin bulunması

Beton basınç dayanımı $10 \mathrm{~cm}$ boyutlarındaki standart küp numunelerin test edilmesiyle saptanmıştır. Numune hazırlanmasında TS EN 12390-2 esas alınmıştır [17]. Buna göre laboratuvar ortamında hazırlanan karışımlar içi hafifçe kalıp yağı ile yağlanmış kalıba iki katman halinde ve her katman $25 \mathrm{kez}$ şişlenerek yerleştirilmiştir. Uygun ortamda 24 saat bekletilen numuneler kalıptan çıkarılıp musluk suyu bulunan kür tanklarında deney yaşına kadar $23 \pm 2^{\circ} \mathrm{C}$ sicaklıkta bekletilmiştir. Kür işlemi tamamlanan numunelerin basınç dayanımları belirlenmiştir. Optimum karışım oranını bulmak için hazırlanan numuneler 7 ve 28; araştırmanın diğer bölümü için hazırlanan numuneler (REF ve 6) ise 7,28 ve 56 günlük yaşlarda test edilmiştir. Şekil 5'te küp numuneler ve test işlemi verilmiştir. 

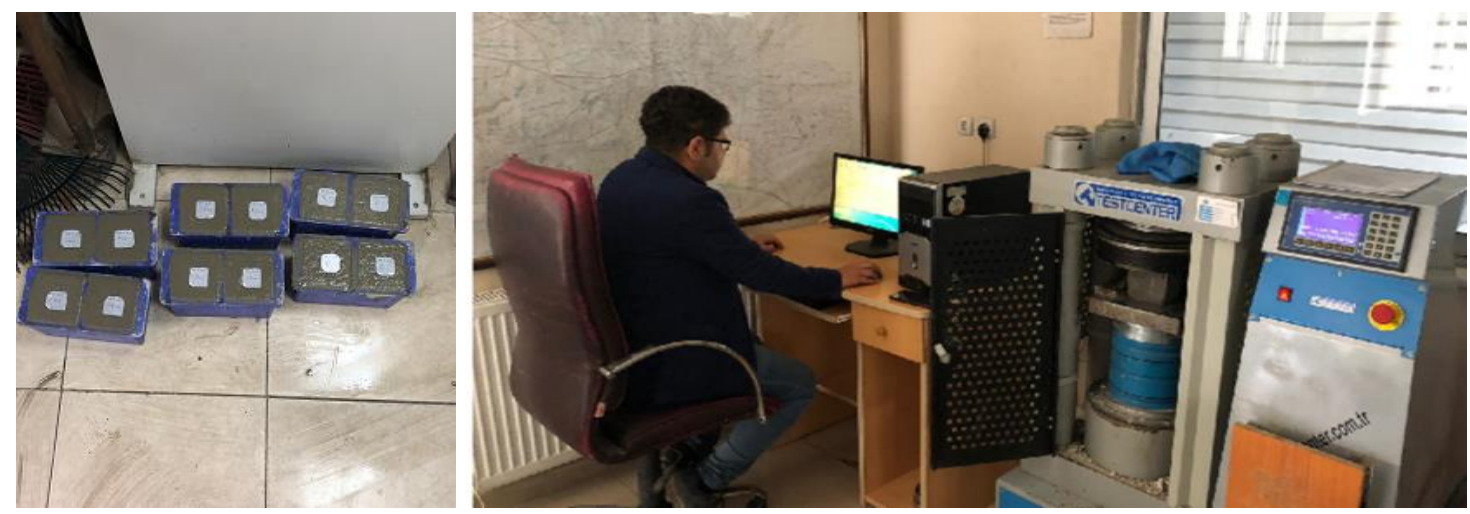

Şekil 5. Bir grup küp numune ve test edilme işlemi

Alkali-silika reaksiyonu hızlandırılmış, ASTM C 1260 standartlarına göre yapılmıştır. Bu yönteme göre REF ve 6 nolu karışım için belirlenen oranlarda alınan bağlayıcı malzeme ve standart kumla $25 * 25 * 285 \mathrm{~mm}$ boyutlarında her karışım için üç adet harç prizması hazırlanmıştır. Hazırlanan numuneler bir gün kalıpta bekletildikten sonra 14 gün, $80^{\circ} \mathrm{C}$ sicakliktaki \%3'lük sodyum hidroksit $(\mathrm{NaOH})$ çözeltisinde bekletilmiştir. Numune boyları, 1 günlük ve 14 günlük $\mathrm{NaOH}$ çözeltisinde bekletilen numuneler üzerinde bulunmuştur. Şekil 3'te kür edilen numuneler ve test işlemi görülmektedir. Alınan bu numunelerin $0,001 \mathrm{~mm}$ duyarlılıkta bir boy ölçer ile boyları belirlenmiştir. Son ölçülen boy-ilk ölçülen boy farkının ilk boya oranlanması ile boy değişim yüzdesi bulunmuştur. Bulunan değerin standardın öngördüğü koşulla karşılaştırılması neticesi alkali-silika reaksiyonu bakımından karışımın uygun olup olmadığı konusunda karar verilmektedir [18]. Şekil 6'da alkali silika reaksiyonunu bulmak için hazırlanan prizma numuneleri ve test işlemi görülmektedir.

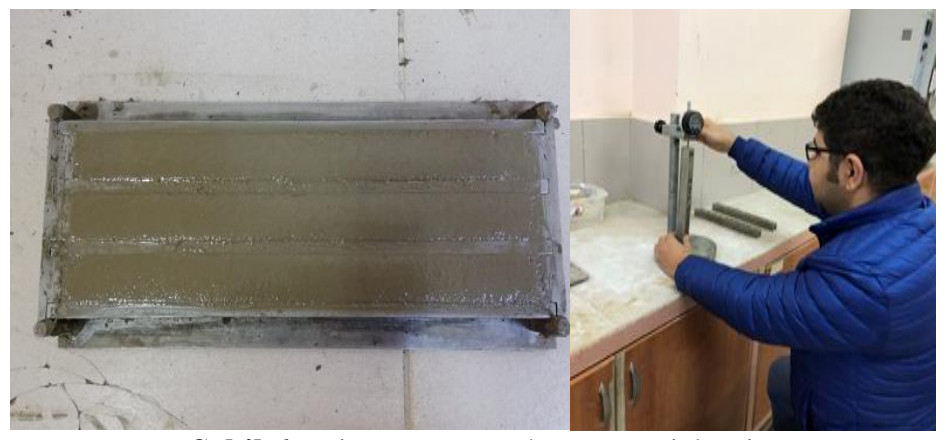

Şekil 6. Prizma numuneler ve test işlemi

Kılcal su emme değerini bulmak için REF ve 6'nolu karışımlardan 3'er adet $10 \mathrm{~cm}$ boyutlu küp numuneler 24 saat $105{ }^{\circ} \mathrm{C}$ 'de etüvde kurutularak etüv kurusu hale getirildi ve kütleleri belirlendi (W1). Sonra numuneler alt yüzeylerinden su ile temas ettirilerek kılcal su emme deneyine tabi tutuldu. Kilcal yolla emilen su miktarının belirlenebilmesi için 60 . dakika sonunda numune tartılarak ağırlığı bulundu $\left(\mathrm{W}_{2}\right)$. Ölçülen değerlerden hareket edilerek kılcallık katsayısı; $\mathrm{kc}=(\mathrm{Q} / \mathrm{A})^{2} \mathrm{x}(1 / \mathrm{t})$ ifadesi ile bulunmuştur [19]. Şekil 7 'de etüvde kurutma işlemi görülmektedir.

$k_{c}=$ Kilcal su emme katsayıs $1\left(\mathrm{~cm}^{2} / \mathrm{s}\right)$

$Q=\mathrm{t}$ zaman aralığında ölçülen su miktarı $\left(\mathrm{cm}^{3}\right)$

$A=$ Kilcal su emme yüzey alanı $\left(\mathrm{cm}^{2}\right)$ 
Afşin-Elbistan Termik Santral Külünün Standarda Uygun Hale Getirilmesi ve Beton Katklsı Olarak Değerlendirilmesi

Çalışmada çabuk donma ve çözülme koşulları altında betonda dayanıklılık faktörü tayini deneyi için Şekil 8'de görülen donma/çözülme cihazı kullanılmıştır. REF ve 6 nolu karışımlardan 3 adet olmak üzere toplam 6 adet $10 \mathrm{~cm}$ boyutlu küp numune teste tabi tutulmuştur. Bunun için numuneler etüvde 24 saat kurutulduktan sonra ilk ağırlıklarının belirlenebilmesi için hassas terazi ile tartılmıştır. REF ve 6 nolu karışıma ait numuneler
2 saat su içerisinde bekletildikten sonra donma/çözülme cihazına konmuştur. Donma/çözülme kabininde $-22{ }^{\circ} \mathrm{C}$ 'de 1,5 saat donma ve 30 dakikada çözülme işlemi otomatik olarak ayarlanmış ve yapılmıştır. $\mathrm{Bu}$ yöntemle 28 çevrim (donma/çözülme) uygulanmıştır. Deney sonunda kütle kaybı ve basınç dayanımı değerlerindeki değişimler incelenmiştir.

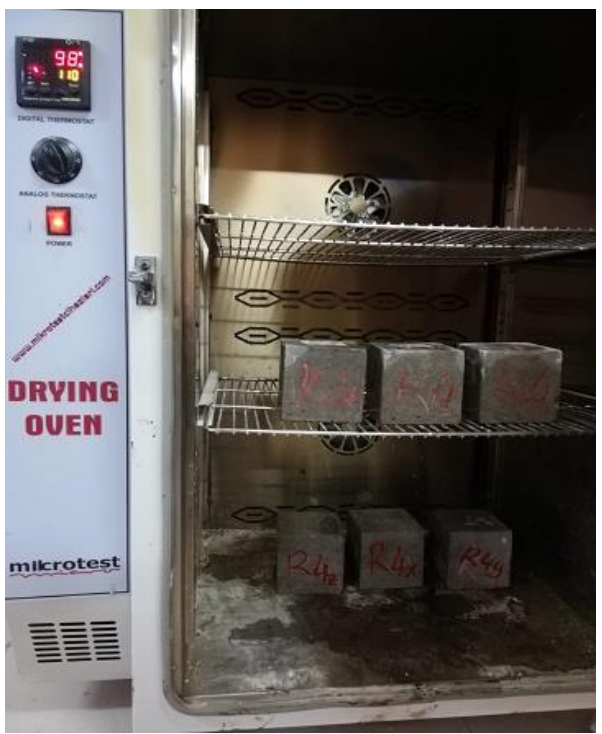

Şekil 7. Numunelerin kurutulması

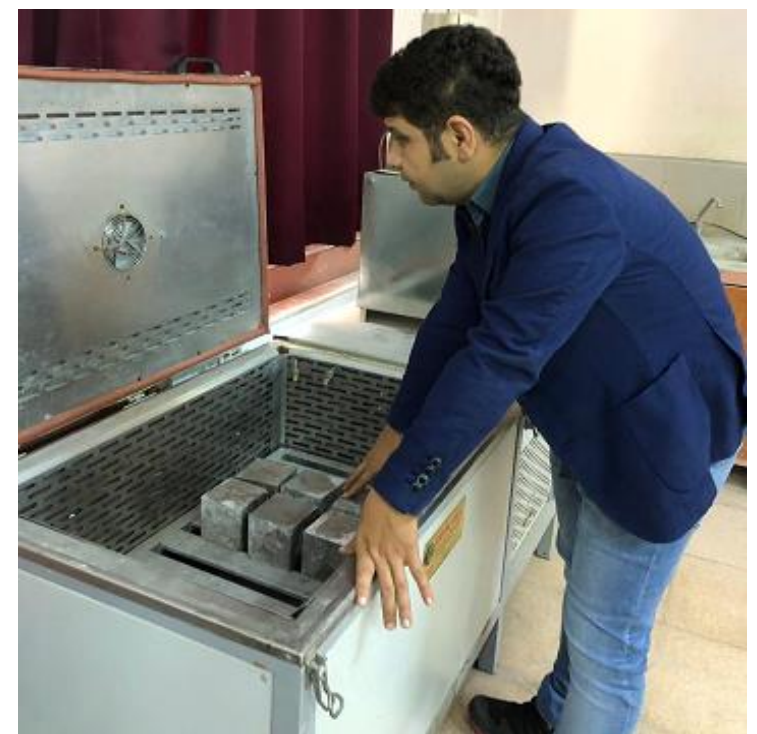

Şekil 8. Donma/çözülme test işlemi
Böhme aşınma değerinin bulunması için Çizelge 4'teki REF ve 6 nolu numunelerden 3'er adet küp numuneler üretilmiştir. Boyutları $71 * 71 * 71 \mathrm{~mm}$ olarak üretilen numuneler 28 gün kürde bekletildikten sonra kurumak üzere etüve bırakılmıştır. 24 saat etüvde bekletilen numuneler çıkarıldıktan sonra hassas terazide tartılmış ve kumpas ile 4 yüzeyinin ölçümü yapılmış ve kaydedilmiştir. Deneyde, başlangıç ağırlıkları bulunarak Böhme cihazının döner diski üzerine yerleştirilen numunelere sabit aşındırma kuvveti uygulanmıştır. Cihazın çalıştırılmasıyla birlikte sürtünme yolu üzerine dökülen $22 \mathrm{~g}$ zımpara tozunun aşındırıcı etkisine maruz bırakılan numuneler, her biri 22 devirden meydana gelen toplam 16 periyotluk aşınma testine tabi tutulmuş ve numunelerin, deney sonundaki kütlesel ve hacimsel aşınma kayıpları belirlenmiştir. Şekil 9'da Böhme cihazı ile aşındırma işlemi görülmektedir [20].

Hamur ve harç numunelerinin mikro yapılarının incelenebilmesi için Scanning Electron Microscope (SEM) taraması yapılmıştır. Hazırlanan yaklaşı $0,5-1 \mathrm{~cm}$ boyutlu numunelerin iletkenliğinin sağlanabilmesi için altın kaplama yapılmıştır. Çimentonun ve çimento+katkı maddelerinin su ile temasi neticesi meydana gelen kimyasal reaksiyonu ve alkali-agrega reaksiyonu sırasında mikro yapıdaki durumun incelenmesi için normal sertleşmiş hamurların 7 ve 28 gün; alkaliagrega testine tabi tutulmuş aynı bağlayıcıya sahip karıșımların ise 120 gün $\mathrm{Na}^{2} \mathrm{SO}_{4}$ ve $\mathrm{MgSO}_{4}$ çözeltilerinde bekletilenlerinden alınan numunelerin iç yapıları SEM ile incelenmiştir. Şekil 10' da SEM cihazı verilmiştir. 


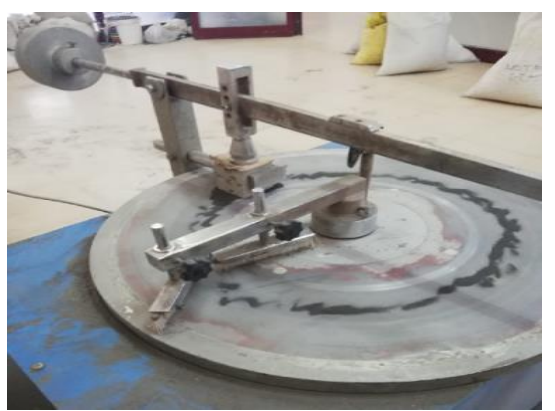

Şekil 9. Böhme cihazı

\section{ARAŞTIRMA BULGULARI}

\subsection{Priz Süresi ve Hacimsel Genleşme}

Priz süresi hacimsel genleşme sonuçları Çizelge 5'te verilmiştir. Çizelge 5'teki priz süreleri ve hacimsel genleşme değerleri incelendiğinde katk1 maddelerinin çimentonun priz sürelerinde büyük miktarda artışa, hacimsel genleşmede ise azalmaya neden olduğu görülmüştür. Priz

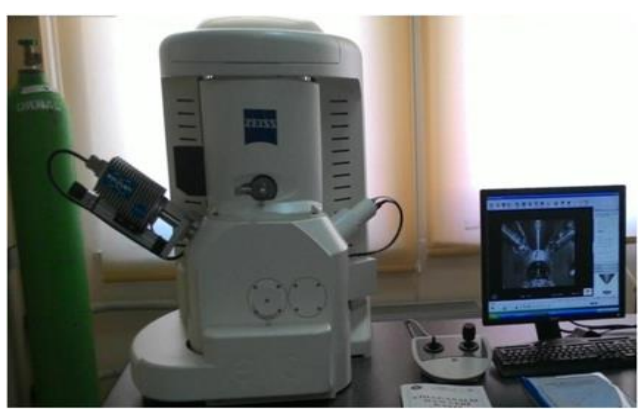

Şekil 10. SEM cihazı

sürelerinin artmasına neden olan en etken katk1 maddesinin kolemanit olduğu söylenebilir. Saptanan bulgular, 21 nolu referansta verilen bulgularla örtüşmektedir [21]. Hacimsel genleşme değerleri standartlara uygundur. Katkıların çimentonun hacimsel genleșme değerini azaltmasının nedeni $\mathrm{MgO}$ oranının düşük olması ve reaksiyona girmeyen $\mathrm{CaO}$ oranını azaltması ile izah edilebilir.

Çizelge 5. Priz süreleri

\begin{tabular}{|l|c|c|c|}
\multirow{2}{*}{ Numune } & \multicolumn{2}{|c|}{ Priz süresi (dk) } & \multirow{2}{*}{ Hacimsel genleşme (mm) } \\
\cline { 2 - 3 } & Başlangıç & Sonu & 2,33 \\
\hline CEM I 42,5 REF & 190 & 290 & 1,5 \\
\hline CEMI $_{60}+\mathrm{KO}_{5}+\mathrm{CT}_{5}+\mathrm{KP}_{10}+\mathrm{AEUK}_{20}$ & 350 & 510 & \\
\hline
\end{tabular}

\subsection{Optimum Karışım Oranı}

Karışıma giren optimum malzeme miktarlarını bulmak için hazırlanan $10 \mathrm{~cm}$ boyutlu deneme küp

numunelerinin ve referans numunenin basınç dayanımları Şekil 11'de görülmektedir.

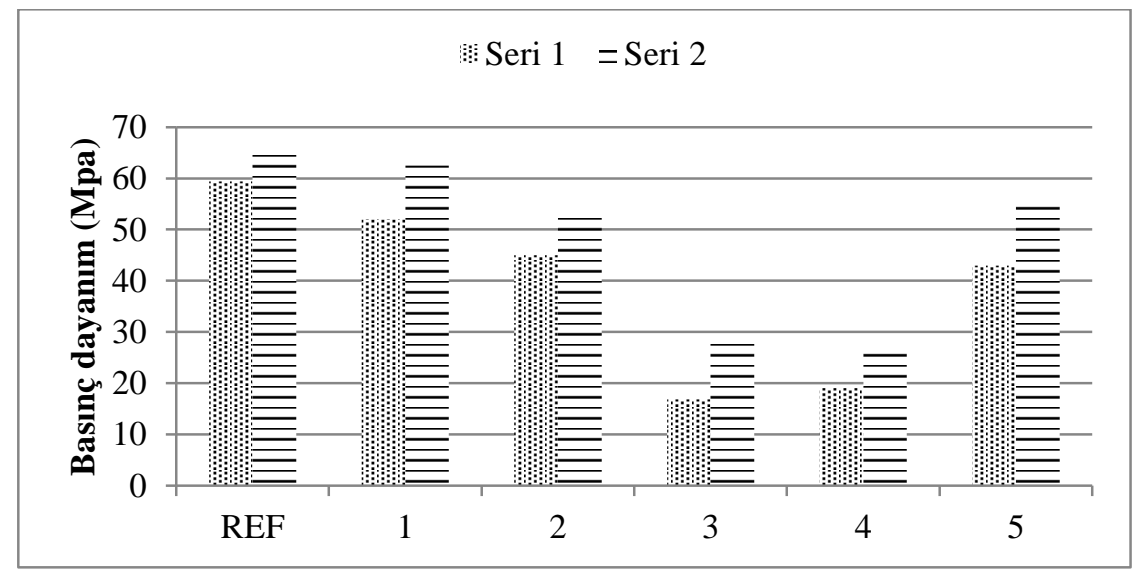

Şekil 11. 7 ve 28 günlük numunelerin basınç dayanımları 
Şekil 11'deki basınç dayanımları incelendiğinde kolemanit oranı $\% 10$ olan 3 . ve 4 . grup numunelerin basınç dayanımları oldukça düşüktür. 3. ve 4. grup numunelerin kalıptan çıkarılma süreleri 4 günü bulmuş ve erken çıkan numunelerde dağılma gözlenmiştir. Her katkı malzemesinden $\% 5$ kullanarak elde edilen 1. grup karışımın 7 ve 28 günlük dayanımları referans numuneye yakın çıkmıştır. 5. grupta çimento $\% 40$ azaltılmış olmasına rağmen 28 günlük dayanım sonucu referans numunenin \%90'1 mertebesinde çıkmıştır. Deneylerde kullanılan süper akışkanlaştırıcıyla referans numunede 7 ve 28 günlük dayanım birbirine yakın çıkmıştır. Yapılan bir çalışmada, farklı özelliklere sahip süper akışkanlaştırıcılardan erken yaşta mukavemet sağlayan katkı kullanıldığında 7 günlük basınç dayanımı, 28 günlük basınç dayanımının \%98'ine kadar yaklaşmakta olduğu sonucuna varılmıştır [22].

\subsection{Basınç Dayanımı}

Referans ve 6 nolu numunelerin 7,28 ve 90 günlük basınç dayanımları Şekil 12'de verilmiştir.

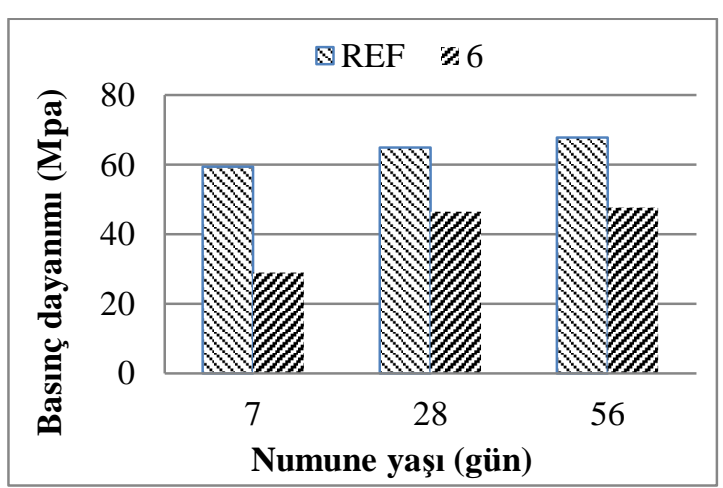

Şekil 12. REF ve 6 nolu numunelerin basınç dayanımları

Sekil 12'de REF ve 6 nolu numunelerin 7, 28 ve 56 günlük basınç dayanımı değerleri incelendiğinde referans numunesinin basınç dayanımının $\mathrm{C} 40$ beton sınıfını sağladığı görülmektedir. 6 nolu karışım numunesinde ise 28 günlük basınç dayanımı değeri C40'ın yaklaşık \%15 altında kalmıştır. Referans numuneye göre, 6 nolu karışımın yaşla dayanım gelişmesi daha yüksek çıkmıştır. Örneğin 6 nolu numunenin 7 günlük dayanımı ile 56 günlük dayanımı arasındaki fark incelendiğinde, 56 günde \%64 artış meydan geldiği görülmektedir. Katkı maddelerinin 6 nolu numunenin ilk yaşlardaki basınç dayanımını düşürdüğü söylenebilir. Bunda kolemanit ve diğer puzolanik maddelerin etkisinin olduğu referanslarca doğrulanmaktadır [21]. Yapılan araştırmada cam tozunun mekanik özelliklere reaktif olması nedeniyle olumlu etkide bulunduğu belirtilmiştir [23]. Araştırmamızda cam tozu tek başına kullanılmadığı için etkisi belirlenememiştir. Hızlandırılmış alkali-silika reaksiyonu deneyine ilişkin 14 günlük boy değişim oranları Şekil 13'te verilmiştir.

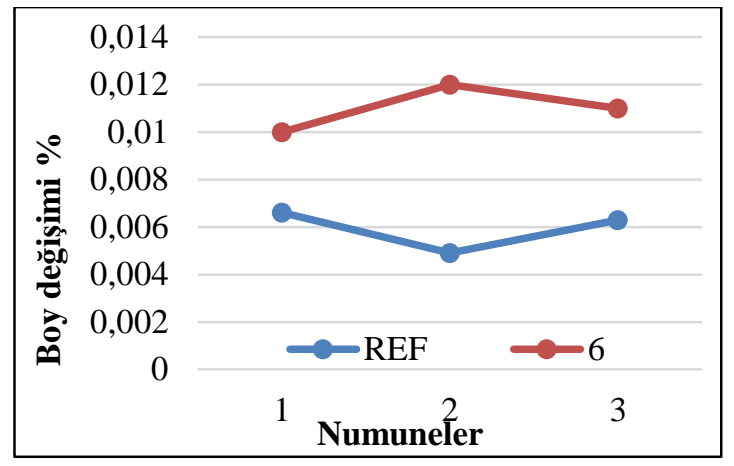

Şekil 13. Alkali-silika reaksiyonu ile boy değişimi

Şekil 13'te alkali-silika reaksiyonu testi neticesi bulunan boy değişim oranları incelendiğinde değerlerin çok düşük olduğu görülmektedir. ASTM C1293-08b standardına göre boy değişimi $\% 0,1$ 'den küçük ise agrega zararsız olarak tanımlanmaktadır. Sonuçların ASTM C 1260 standardına göre 14 günlük boy değişimininin maksimum sınırının altında kaldığı görülmüștür. Yine Şekil 10'dan 6 nolu karışım numunesinin boy değişiminin REF numunesine göre daha fazla olduğu anlaşılmaktadır. Bunun sebebi olarak karışım numunesindeki alkalilerin $\left(\mathrm{Na}_{2} \mathrm{O}\right.$ ve $\left.\mathrm{K}_{2} \mathrm{O}\right)$ oranının referans numunesinden daha fazla olması gösterilebilir. Alkali-silika reaksiyonu, genellikle çimentodan kaynaklanan alkali $\left(\mathrm{Na}_{2} \mathrm{O}\right.$ ve $\left.\mathrm{K}_{2} \mathrm{O}\right)$ reaktif silika formları içeren agregalar arasında oluşan ve betonda genleşme etkisine sebep olan kimyasal bir reaksiyondur [24]. Araştırmada alkali-silika reaksiyonu sonucu bulunan değerler referans tarafından doğrulanmaktadır. 


\subsection{Kılcal Su Emme ve Donma Çözülme}

Çalışmada REF ve 6 nolu numuneler üzerinde kılcal su emme ve donma/çözülme işlemi sonrası basınç dayanımı kayıpları Çizelge 6'da verilmiştir.

Çizelge 6'da görüldüğü gibi referans numunesine göre 6 nolu katkılı numunede bulunan ortalama kılcal su emme katsayısı ve donma/çözülme sonrası basınç dayanımı kaybı sırasıyla \%25 ve $\% 14$ daha düşük bulunmuştur. Bunun anlamı 6 nolu numune dahja az geçirimli ve donma/çözülme olayından daha az etkilenmektedir. Bunun gerekçesi, mineral katkıların incelikleri ve reaksiyona girmeyen $\mathrm{CaO}$ ile reaksiyona girmeleri şeklinde açıklanabilir.

\section{Çizelge 6. Numunelerin kılcal su emme deneyi sonuçları}

\begin{tabular}{|c|c|c|c|}
\hline Numune & $\begin{array}{c}\text { Ortalama k1lcal su emme } \\
(\mathrm{g})\end{array}$ & $\begin{array}{c}\text { Ortalama k1lcal su emme } \\
\text { katsay1s1 }\left(\mathrm{cm}^{2} / \mathrm{s}\right)(\mathrm{kc})\end{array}$ & $\begin{array}{c}\text { Ortala donma/çözülme } \\
\text { kayb1 }(\%)\end{array}$ \\
\hline REF & 14,24 & $4,7^{*} 10^{-6}$ & 15,92 \\
\hline 6 & 11,14 & $3,5^{*} 10^{-6}$ & 13,68 \\
\hline
\end{tabular}

\subsection{Mekanik Aşınma Kaybı}

Böhme yöntemiyle bulunan aşınma kayıpları Şekil 14'te verilmiştir. Şekil 14'teki örneklerin aşınma kayıpları incelendiğinde karışım numunelerinin aşınma kayıplarının daha fazla olduğu anlaşılmaktadır. Ancak bağıntıdaki formülde referans ve karışım numunelerindeki hacimsel kayiplar sirasiyla $8570 \mathrm{~mm}^{3} / 5000 \mathrm{~mm}^{2}$ ve $10660 \mathrm{~mm}^{3} / 5000 \mathrm{~mm}^{2}$, dir. Her iki değer de TS EN 1338 standardında yer alan $\leq 18000 \mathrm{~mm}^{3} / 5000$ $\mathrm{mm}^{2}$ değerini sağladığından sorun teşkil etmemektedir.

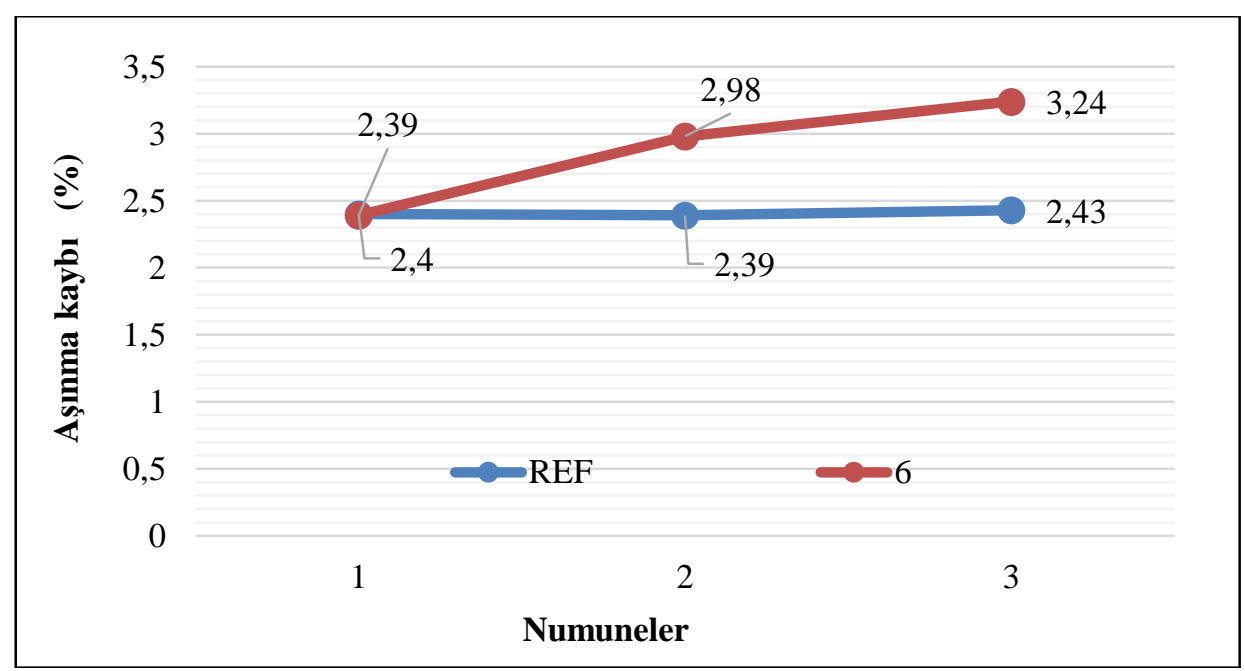

Şekil 14. 28 Günlük betonların mekanik aşınma kayıpları

\subsection{Mikro Yapı}

Çimentonun ve çimento+katkı maddelerinin su ile temas1 neticesi meydana gelen kimyasal reaksiyonu ve alkali-agrega reaksiyonu sirasında mikro yapıdaki durumun incelenmesi için normal sertleşmiş hamurların 7 ve 28 gün; alkali-agrega testine tabi tutulmuş aynı bağlayıcıya sahip karışımların ise 120 gün $\mathrm{Na}_{2} \mathrm{SO}_{4}$ ve $\mathrm{MgSO}_{4}$ çözeltilerinde bekletilenlerinden alınan numunelerin iç yapıları SEM ile incelenmiştir. SEM resimleri Şekil 15, 16, 17, 18'de görülmektedir. 

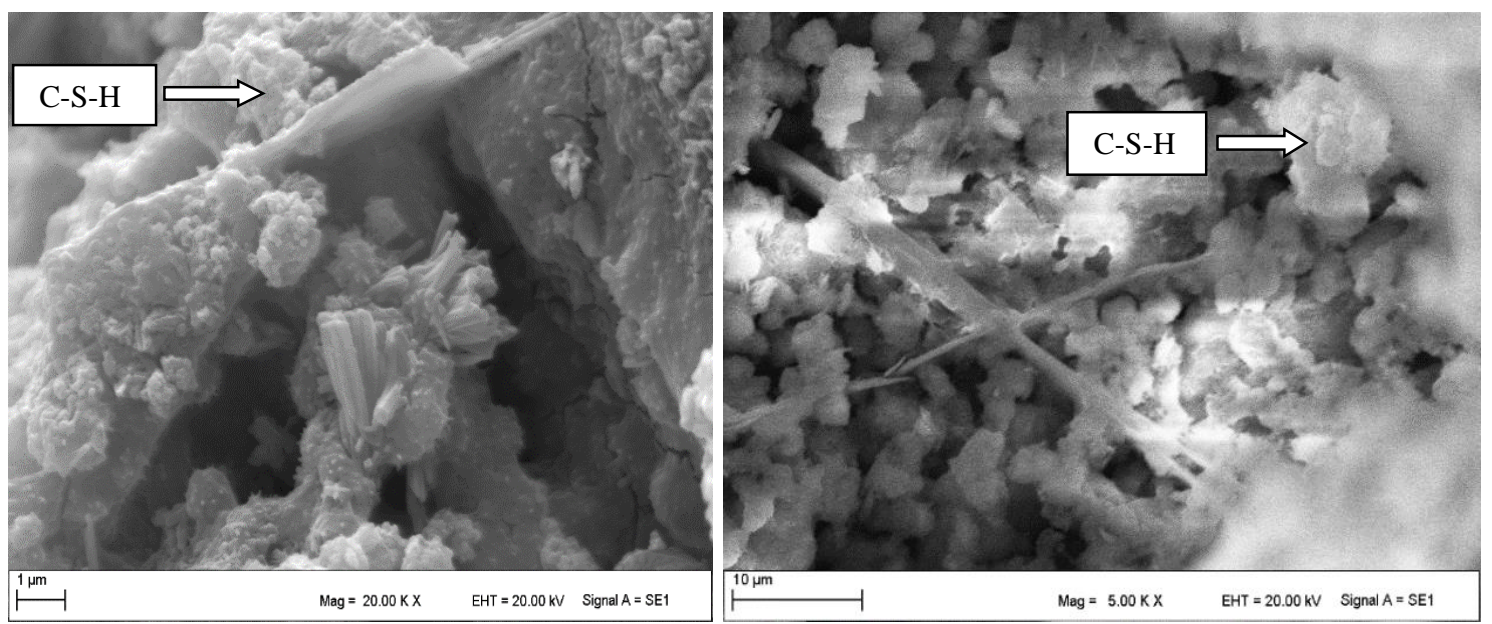

Şekil 15. REF numunelerinin 7 ve 28 günlük SEM görüntüleri

Şekil 15'te REF numunesinin bağlayıcı maddesi olan CEM I 42,5R çimentosuna ait sertleşmiş 7 ve 28 günlük hamurların SEM resimleri incelendiğinde beklendiği gibi reaksiyon

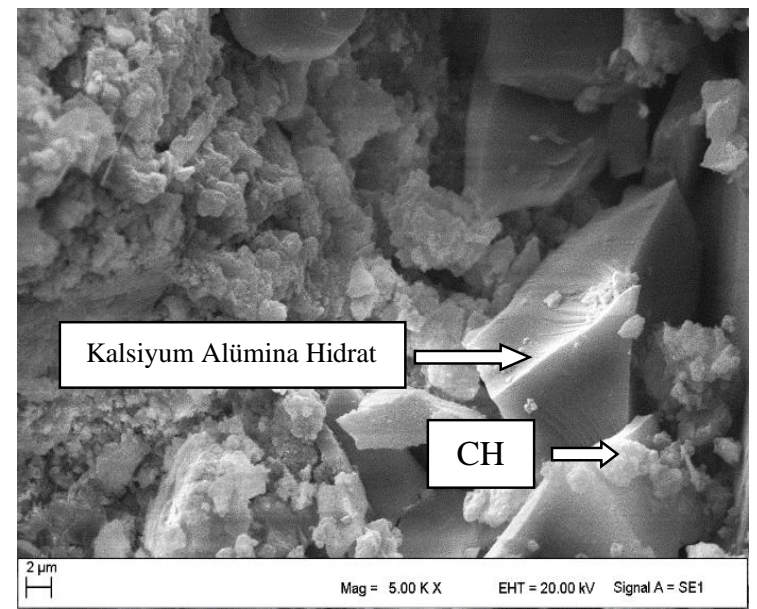

Şekil 16. 6 nolu numunelerin 7 ve 28 günlük SEM görüntüleri

Şekil 16'da verilen 6 nolu katkılı numunenin bağlayıcı maddelerinin 7 ve 28 günlük sertleşmiş hamurlarının SEM resimlerinden reaksiyonun meydana geldiği görülmektedir. 7 günlük numunede 28 güne göre daha fazla oranda $\mathrm{CH}$, etrenjit ve kalsiyum alümina hidratların oluştuğu görülmektedir. 28 günlük numunede ise C-S-H jeli oranı artmıştır. bileşiklerinin meydana geldiği görülmektedir. 28 günlük hamur görüntüsünde 7 güne göre $\mathrm{C}-\mathrm{S}-\mathrm{H}$ oranının arttığı $\mathrm{CH}$ oranının azaldığ görülmektedir.

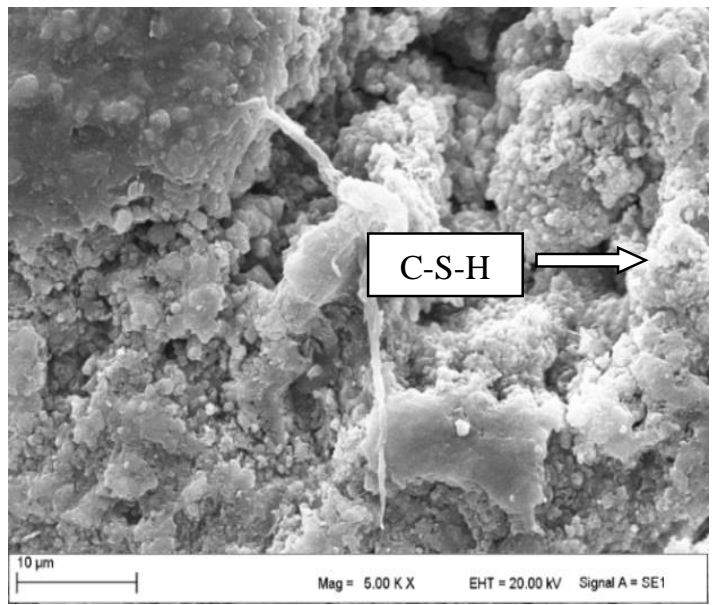

Şekil 17'de 120 gün $\mathrm{Na}_{2} \mathrm{SO}_{4}$ ve $\mathrm{MgSO}_{4}$ çözeltilerinde bekletilen referans harç prizmasından alınan numunelerin SEM görüntüleri incelendiğinde her iki çözeltide de etrenjitin arttığ1 tomasit meydana geldiği görülmektedir. Tomasitin beton üzerindeki davranışları bazı kaynaklarla araştırılmıştır [25-27]. Etrenjit ve tomasit oranı $\mathrm{MgSO}_{4}$ çözeltisinde bekletilen numunede daha fazla meydana gelmiştir. 

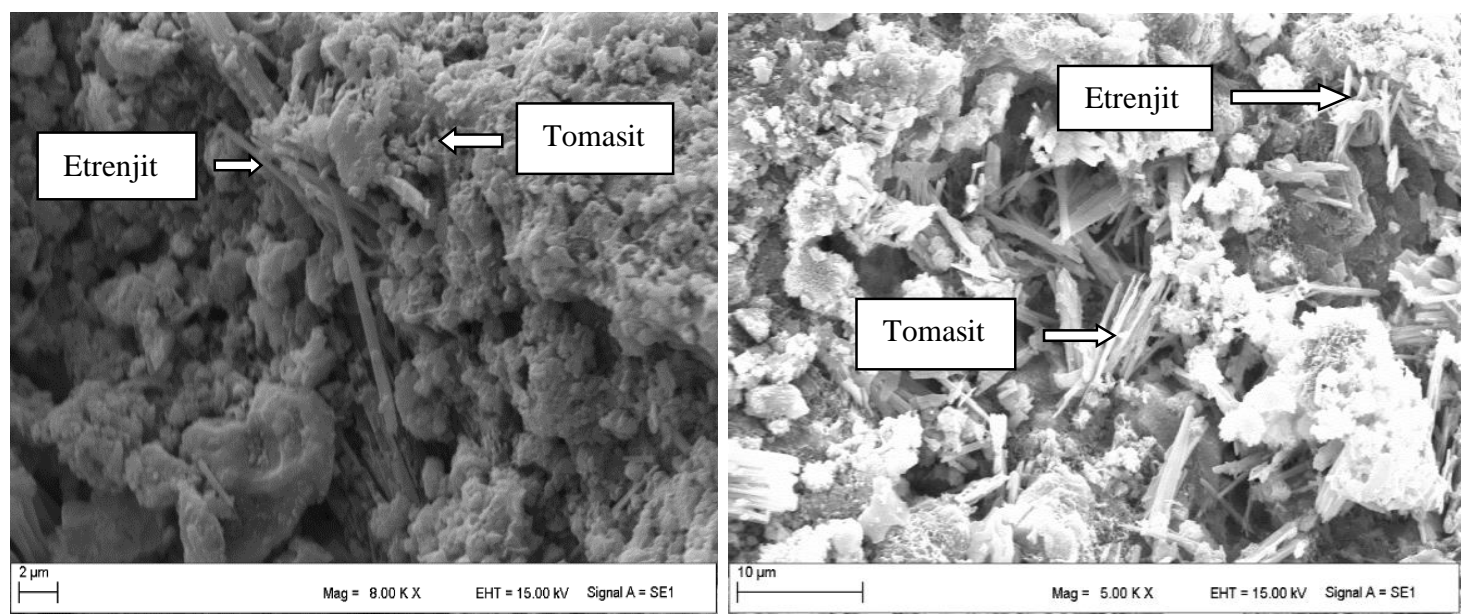

Şekil 17. 120 gün $\mathrm{Na}_{2} \mathrm{SO}_{4}$ ve $\mathrm{MgSO}_{4}$ çözeltilerinde bekletilen $\mathrm{R}$ numunesinin $\mathrm{SEM}$ görüntüleri
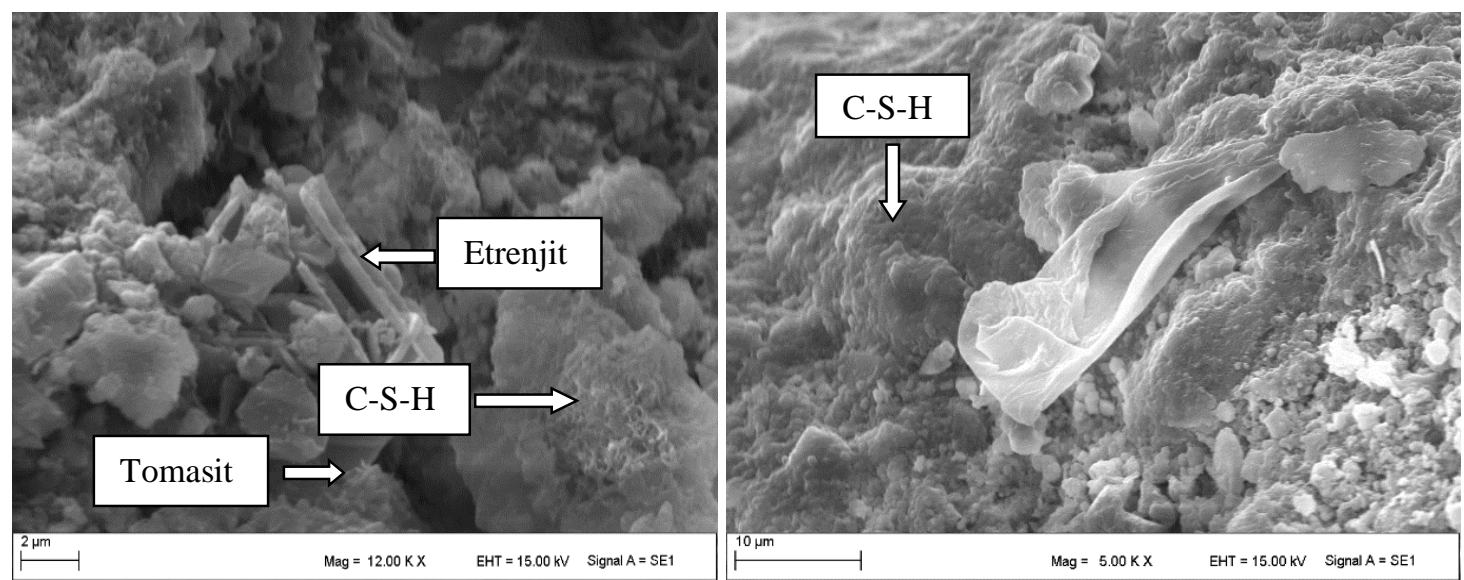

Şekil 18. 120 gün $\mathrm{Na}_{2} \mathrm{SO}_{4}$ ve $\mathrm{MgSO}_{4}$ çözeltilerinde bekletilen 6 nolu numunenin SEM görüntüleri

Şekil 18'de 120 gün $\mathrm{Na}_{2} \mathrm{SO}_{4}$ ve $\mathrm{MgSO}_{4}$ çözeltilerinde bekletilen 6 nolu harç prizmasından alınan numunelerin SEM görüntüleri incelendiğinde $\mathrm{Na}_{2} \mathrm{SO}_{4}$ çözeltisinde bekletilmiş numunede etrenjit ve tomasit ve boşlukların daha fazla olduğu görülmektedir. $\mathrm{MgSO}_{4}$ çözeltisinde bekletilen numunede ise daha yoğun $\mathrm{C}-\mathrm{S}-\mathrm{H}$ jeli meydana geldiği görülmektedir. Bu duruma göre 6 nolu numunenin $\mathrm{MgSO}_{4}$ içeren ortamlara karşı daha dirençli olduğunu göstermektedir. Sülfatların kalsiyum silikatlar (C-S-H) üzerine etkimesi sonucu oluşan ve 15 molekül su içeren tomasit tuzu da genleşerek ve özellikle betonu yumuşatarak hasar yapar [24]. Bulgular referans tarafından doğrulanmaktadır.

\section{SONUÇLAR}

Uçucu külün kimyasal yapısının uygun hale getirilmesi ile reaksiyona girmeyen $\mathrm{CaO}$ oranı azaltılmış, C-S-H oranı artmış ve etrenjit miktarı azaltılmıştır.

AEUK'nın \%20 oranında betona katılması ideal bir çözüm olarak görülmektedir. Çimentonun ikamesi olarak kolemanitin \%5'ten fazla kullanılmasının beton prizini engellediği ve basınç dayanımına olumlu katkı sağlamadığ düşünülebilir. Cam tozunun basınç dayanımına olumlu katkı sağladığı anlaşılmaktadır. Kayseri pomzasının kimyasal içeriği uygun olmasına 
Afşin-Elbistan Termik Santral Külünün Standarda Uygun Hale Getirilmesi ve Beton Katklsı Olarak Değerlendirilmesi

karşın özgül ağırlığı düşük olması nedeniyle AEUK ile birlikte kullanılması yüksek mukavemetli beton üretiminde önerilmemektedir.

Elde edilen mineral katkının priz süresini uzattığı görülmüştür. Katkılı çimento hamurunun genleşmesi ile ilgili standart bakımından sorun teşkil etmemektedir. Priz süresinin uzaması nedeniyle kütle betonu için önerilebilir.

Alkali-Silika reaksiyonu incelendiğinde referans numuneye göre karışım numunesinin boy değişiminin arttığ 1 gözlenmiştir.

Karışım numunesinin standart değeri sağlamasına rağmen referans numuneden daha fazla aşındığ gözlemlenmiştir.

28 günlük mikro yap1 incelendiğinde katk1 malzemelerinin zararlı etrenjit oluşumunu önlemede katkı sağladığı düşünülebilir.

Atık camların öğütülüp betonda puzolanik katkı olarak kullanımı çimento kullanımını azaltacağ1 için, çimento üretim tesislerinden kaynaklanan karbondioksit gibi sera gazlarının yayılmasını \% 10-15 oranında azaltacaktır.

$\checkmark$ Ancak, dayanıklılık araştırması için 120 gün kısa bir süre olarak kabul edilebilir.

\section{KAYNAKLAR}

1. İklim Haber, 2020, 2019'da Elektrik Üretimi Azald1: Kömür Hala Birinci Kaynak, https://www.iklimhaber.org/2019da-elektrikuretimi-azaldi-komur-hala-birinci-kaynak/, (Erişim zamanı: 23 Şubat, 2020).

2. Özkul, H., Taşdemir, M.A., Tokyay, M. ve Uyan, M., 2004. Her Yönüyle Beton. Hazır Beton Birliği, İstanbul, 128.

3. Erdoğan, T.Y., 2010. Beton. ODTU Yayıncılık, Ankara, 760.

4. Aruntaş, H.Y., 2006. Uçucu Küllerin İnşaat Sektöründe Kullanım Potansiyeli. Gazi Üniversitesi, Mühendislik Mimarlık Fakültesi Dergisi, 21(1), 193-203.
5. Temiz, H., Binici, H., Coşkun, İ., 2010. Volkanik Cüruf İlave Edilmiş Uçucu Kül Katkılı Betonların Özellikleri. Hazır Beton Dergisi, 97, 75- 82.

6. Tulga, İ., Kılınç, K., 2018. Uçucu Kül Kullanımının Farklı Dayanım Sınıflarındaki Betonların Mekanik ve Durabilite Özellikleri Üzerindeki Etkisi. Kırklareli Üniversitesi Journal of Engineering and Science Dergisi, 4(2), 212-236.

7. Klemczak, B., M. Batog., Z., Giergiczny, A., Zmij, 2018. Complex Effect of Concrete Composition on The Thermo-mechanical Behaviour of Mass Concrete. Journal of Materials (Basel), 11(11), 1-18.

8. Türker, P., Erdoğan, B., Katnaş, F., Yeğinobal1, A., 2007. Türkiye'deki Uçucu Küllerin Sınıflandırılması ve Özellikleri. Türkiye Çimento Müstahsilleri Birliği. AR-GE Enstitüsü, Ankara, 114.

9. Temiz, H., Akçakale, A.H., 2014. Hafif Agregalı Betonun Mühendislik Özelliklerinin Araştırılması. Karaelmas Fen ve Mühendislik Dergisi, 4(2), 7-20.

10. Gündüz, L., Sarışı, A., Tozaçan, B., Davraz, M., Uğur, İ., Çankıran, O., 1998. Pomza Teknolojisi. Süleyman Demirel Üniversitesi, Fen Bilimleri Enstitüsü Dergisi, 1, 275-285.

11. Uluköy, A., Can, A.Ç., 2006. Çeliklerin Borlanmas1. Mühendislik Bilimleri Dergisi, 12(2), 189-198.

12. Aladdine, F., Laldji, S. And Tagnit-Hamou, A., 2009. Glass Powder as an Alternative Cementitious Material in Concrete. in: $10^{\text {th }}$ ACI Int. Conf. Recent Advances in Concrete Technologies and Sustainability Issues, Seville, Espagne, 683-698.

13. Uzun, M., Çöğürcü, M.T., Keskin, Ü.S., 2018. Cam Tozunun Beton Basınç Dayanımına Etkisi. Beykent Üniversitesi, Fen Bilimleri Dergisi, 11(2), 42-51.

14. TS 802, 2009. Beton Karışım Hesabı, Ankara.

15. TS EN 12620, 2003. Beton Agregalar1, Ankara.

16. TS EN 196-3, 2002. Çimentonun Priz Süresi ve Genleşmesi, Ankara.

17. TS EN 12390-2, 2019. Dayanım Deneylerinde Kullanilacak Deney Numunelerinin Hazırlanması ve Küre Tabi Tutulması, Ankara. 
18. ASTM C1293-08b, 2008. Standard Test Method for Determination of Length Change of Concrete Due to Alkali-Silica Reaction. PA, USA.

19. TS EN 772-11, 2011. Betondan, Yapay Taş ve Doğal Taştan Yapılmış Kagir Birimlerde Kapiler Etki ile (Kılcal) Su Emme Katsayısı ve Kil Kagir Birimlerde İlk Su Emme Hızının Tayini, Ankara.

20.TS EN 1338, 2005. Zemin Döşemesi İçin Beton Kaplama Blokları-Gerekli Şartlar ve Deney Metotları, Ankara.

21. Bideci, Ö.S. ve Bideci, A., 2018. Öğütülmüş Kolemanit Katkısının Çimento Harçlarına Etkisi. Fırat Üniversitesi, Mühendislik Bilimleri Dergisi, 30(1), 133-138.

22. Çorbacioğlu, C.U., 2008. Beton Karışım Tasarımının Geçirimliliğe ve Mekanik Özelliklere Etkisi. İstanbul Teknik Üniversitesi, Fen Bilimleri Enstitüsü, Yüksek Lisans Tezi, İnşaat Mühendisliği Anabilim Dalı, İstanbul, 90.

23. Uzun, M., Çöğürcü, M.T., Keskin, Ü.S., 2018. Cam Tozunun Beton Basınç Dayanımına Etkisi. Beykent Üniversitesi, Fen Bilimleri Dergisi, 11(2), 42-51.

24. Baradan, B., Aydın, S., 2013. Betonun Durabilitesi (Dayanıklılık, Kalıcılık). Hazır Beton Dergisi, 120, 54-68.

25. Ashraf, H.M. Abdalkader, 2014. Thaumasite Sulfate Attack in Cement Mortars Exposed to Sulfate and Chloride and Implications to Rebar Corrosion. PhD Thesis, The University of Sheffield, Department of Civil and Structural Engineering, Sheffield, 232.

26. Mingyu, H., Fumei, L., Mingshu, T., 2006. The Thaumasite Form of Sulfate Attack in Concrete of Yongan Dam, Cement and Conrete Research, 36(10), 2006-2008.

27. Baradan, B., Yazıcı, H., Ün, H., 2010. Beton ve Betonarme Yapılarda Kalıcılık (Durabilite). Türkiye Hazır Beton Birliği, İstanbul, 318. 
